\title{
PEMBELAJARAN MATEMATIKA BERBASIS MASALAH DENGAN STRATEGI INKUIRI TERBIMBING DAN INKUIRI BEBAS TERMODIFIKASI DITINJAU DARI KEMAMPUAN AWAL SISWA MTS
}

\author{
Eko Diah Cahyani \\ MTs Ta'mirul Islam Surakarta \\ ekodiah@gmail.com
}

\begin{abstract}
The purposes of this study are (1) to test the effect difference of problem based learning strategies guided inquiry and modified free inquiry on student learning outcomes, to (2) test the effect difference early ability categories of high, medium and low student to student learning outcomes, and (3) to test the interaction between early ability category strategy with high, medium and low student to student learning outcomes. This type of research is quantitative with quasi experiment Desain. The population are all students of class VII MTs Ta'mirul Islam Surakarta. The research sample two classes. The sampling technique is cluster random sampling by lottery. Data collection techniques used cognitive testing and documentation. Data were analyzed using analysis of variance of two different cell. The results of the study with $\alpha$ $=5 \%$. The results are (1) there are differences in the effect of problem-based learning strategies guided inquiry and modified free inquiry on student learning outcomes, (2) there are differences in the effect of the initial capabilities categories of high, medium and low student to student learning outcomes, and (3) there is no interaction between early ability category strategy with high, medium and low student to student learning outcomes.
\end{abstract}

Keywords: student learning outcomes, initial capabilities, guided inquiry, inquiry freely modified

Abstrak. Tujuan penelitian adalah (1) menguji perbedaan pengaruh pembelajaran berbasis masalah dengan strategi inkuiri terbimbing dan inkuiri bebas termodifikasi terhadap hasil belajar siswa. (2) menguji perbedaan pengaruh kemampuan awal kategori tinggi, sedang dan rendah siswa terhadap hasil belajar siswa. (3) menguji interaksi antara strategi dengan kemampuan awal kategori tinggi, sedang dan rendah siswa terhadap hasil belajar siswa. Jenis penelitian ini kuantitatif dengan desai eksperimen semu. Populasi penelitian seluruh siswa kelas VII MTs Ta'mirul Islam Surakarta. Sampel penelitian dua kelas. Teknik pengambilan sampel cluster random sampling dengan undian. Teknik pengumpulan data dengan metode tes kognitif dan dokumentasi. Teknik analisis data menggunakan analisis variansi dua jalan sel tak sama. Hasil penelitian dengan $\alpha=5 \%$. (1) Ada perbedaan pengaruh pembelajaran berbasis masalah dengan strategi inkuiri terbimbing dan inkuiri bebas termodifikasi terhadap hasil belajar siswa. (2) Ada perbedaan pengaruh kemampuan awal kategori tinggi, sedang dan rendah siswa terhadap hasil belajar siswa. (3) Tidak ada interaksi antara strategi dengan kemampuan awal kategori tinggi, sedang dan rendah siswa terhadap hasil belajar siswa.

Kata kunci: hasil belajar siswa, kemampuan awal, inkuiri terbimbing, inkuiri bebas termodifikasi 


\section{Pendahuluan}

Mata pelajaran Matematika perlu diberikan kepada semua peserta didik mulai dari sekolah dasar sampai menengah untuk membekali mereka dengan kemampuan berfikir logis, analitis, sistematis, kritis, kreatif, cermat, efektif dan efisien serta kemampuan bekerja sama dalam pemecahan masalah. (lampiran Permendiknas N0 23 Tahun 2006). Karena matematika merupakan salah satu cabang ilmu pengetahuan yang mempunyai peranan penting dalam perkembangan ilmu pengetahuan dan teknologi, baik sebagai alat bantu dalam penerapan-penerapan bidang ilmu lain maupun dalam pengembangan matematika itu sendiri.

Hasil studi dari trends in international mathematics and science study (TIMSS), pembelajaran matematika di Indonesia berada di peringkat bawah. Rata-rata prestasi belajar matematika di Indonesia berdasarkan TIMSS pada tahun 2011, Indonesia menduduki peringkat 38 dari 42 negara. Sedangkan berdasarkan survei yang dilakukan oleh PISA ( Program For International Student Assesment ) kemampuan siswa di Indonesia menduduki peringkat 64 dari 65 negara. Rendahnya prestasi belajar matematika siswa di Indonesia bisa disebabkan oleh dua hal diantaranya strategi pembelajaran yang monoton serta kemampuan pemecahan masalah yang masih rendah. Di tingkat nasional, pelaksanaan UN di tingkat SMP/ MTs yang terdiri dari Matematika, IPA, Bahasa Indonesia dan Bahasa Inggris yang gunanya untuk mengukur kompetensi kelulusan siswa. Rendahnya kompetensi Matematika siswa di Indonesia juga tercermin dari hasil ujian nasional (UN). Pada hasil UN tahun 2014/2015 rata-rata matematika pada UN di tingkat nasional yaitu 56,27 (Litbang Kemendikbud, 2015).

Sanjaya (2011: 13) mengemukakan bahwa hasil belajar berkaitan dengan pencapaian dalam memperoleh kemampuan sesuai dengan tujuan khusus yang direncanakan. Dengan demikian, tugas utama guru dalam kegiatan ini adalah merancang instrumen yang dapat mengumpulkan data tentang keberhasilan siswa dalam mencapai tujuan pembelajaran. Berdasarkan pengamatan dan wawancara peneliti dengan beberapa guru Matematika kelas VII di MTs Ta'mirul Islam Surakarta. Banyak masalah yang terjadi, mengingat siswa masih menganggap matematika pelajaran momok dan sulit. Kebanyakan siswa mengalami kesulitan dalam mengaplikasikan matematika ke dalam situasi kehidupan real. Hal lain yang menyebabkan sulitnya matematika bagi siswa adalah karena pembelajaran matematika kurang bermakna. Guru dalam pembelajarannya di kelas juga masih menggunakan strategi yang bersifat monoton/ kurang bervariasi atau masih bersifat teacher oriented sehingga siswa kurang diberikan kesempatan untuk menemukan kembali dan mengkonstruksi sendiri ide-ide matematika. Pembelajaran matematika selama ini masih kurang melibatkan siswa secara aktif serta guru masih meminta siswa untuk menghafal rumus.

Faktor yang mempengaruhi hasil belajar menurut Richard Clark dalam Sudjana (2005 : 39) adalah faktor dari dalam diri siswa itu dan faktor dari luar diri siswa atau faktor lingkungan. Faktor yang datang dari diri siswa terutama kemampuan yang dimilikinya. Faktor kemampuan siswa besar sekali pengaruhnya terhadap hasil belajar yang dicapai. Menurut Clark mengemukakan bahwa hasil belajar siswa di sekolah 70\% dipengaruhi oleh kemampuan siswa dan 30\% dipengaruhi oleh lingkungan.

Berdasarkan permasalahan tersebut, salah satu alternatif solusi yang dilakukan yaitu penerapan strategi pembelajaran yang inovatif dengan memperhatikan kemampuan awal siswa sehingga diperoleh hasil belajar yang lebih baik. Pembelajaran akan berhasil jika menggunkan metode yang dapat menuntut siswa aktif. Strategi inkuiri merupakan sebuah strategi yang menuntut siswa aktif pada proses pembelajaran agar menemukan suatu konsep. Penerapan strategi inkuiri dalam pembelajaran dapat dilakukan 
secara terbimbing dan bebas termodifikasi. Penerapan strategi ini diharapkan dapat membawa siswa lebih aktif dalam kegiatan pembelajaran, mengembangkan keterampilan, meningkatkan kemampuan kognitif, dan dapat lebih memahami pelajaran matematika sehingga dapat meningkatkan hasil belajar.

Sanjaya (2011: 196) berpendapat bahwa Pembelajaran inkuiri adalah rangkaian kegiatan pembelajaran yang menekankan pada proses berfikir secara kritis dan analitis untuk mencari dan menemukan sendiri jawaban dari suatu masalah yang dipertanyakan. Proses pembelajaran inkuiri dilakukan melalui tahapan-tahapan sebagai berikut adalah : 1) orientasi, 2) merumuskan masalah, 3) mengajukan hipotesis, 4) mengumpulkan data, 5) menguji hipotesis, 6) merumuskan kesimpulan. (Sanjaya, 2011: 201)

Menurut Robert B.Sund, Leslie W. Trowbridge (dalam Fathurrohman, 2015 : 106-107) Pembelajaran inkuiri terbimbing yaitu strategi pembelajaran inkuiri yang dalam pelaksanaannya guru menyediakan bimbingan atau petunjuk cukup luas kepada peserta didik. Strategi pembelajaran inkuiri bebas termodifikasi memiliki ciri guru hanya memberikan permasalahan tersebut melalui pengamatan, percobaan, atau prosedur penelitian untuk memperoleh jawaban. Disamping itu, guru merupakan narasumber yang tugasnya hanya memberikan bantuan yang diperlukan untuk menghindari kegagalan dalam pemecahan masalah. Jika peserta didik tidak mengalami kegagalan dan mampu memecahkan masalahnya, guru hanya sebagai fasilitator saja.

Selain strategi pembelajaran, kemampuan awal yang berbeda-beda juga dapat mempengaruhi hasil belajar siswa. Setiap individu mempunyai kemampuan belajar yang berlainan. Kemampuan awal siswa adalah kemampuan yang telah dimiliki oleh siswa sebelum ia mengikuti pembelajaran yang akan diberikan. Kemampuan awal (entry behavior) ini menggambarkan kesiapan siswa dalam menerima pelajaran yang akan disampaikan oleh guru. Kemampuan awal siswa penting untuk diketahui guru sebelum ia mulai dengan pembelajarannya, karena dengan demikian dapat diketahui: a) apakah siswa telah mempunyai atau pengetahuan yang merupakan prasyarat (prerequisite) untuk mengikuti pembelajaran; b) sejauh mana siswa telah mengetahui materi apa yang akan disajikan (Sumantri,2015: 183).

Berdasarkan uraian tersebut dapat diajukan tiga hipotesis. (1) Ada perbedaan yang signifikan antara pembelajaran berbasis masalah dengan strategi inkuiri terbimbing dan strategi inkuiri bebas termodifikasi terhadap hasil belajar siswa. (2) Ada perbedaan yang signifikan antara kemampuan awal siswa dengan kategori tinggi, kategori sedang dan kategori rendah terhadap hasil belajar siswa. (3) Ada interaksi antara strategi dengan kemampuan awal siswa dengan kategori tinggi, kategori sedang dan kategori rendah terhadap hasil belajar Siswa.

Tujuan penelitian ini ada tiga. (1) Menguji perbedaan pengaruh pembelajaran berbasis masalah dengan strategi inkuiri terbimbing dan strategi inkuiri bebas termodifikasi terhadap hasil belajar siswa. (2) Menguji perbedaan pengaruh kemampuan awal kategori tinggi, kategori sedang dan kategori rendah siswa terhadap hasil belajar siswa. (3) Menguji interaksi antara strategi dengan kemampuan awal kategori tinggi, kategori sedang dan kategori rendah siswa terhadap hasil belajar siswa.

\section{Metode Penelitian}

Jenis penelitian ini adalah kuantitatif. Metode penelitian yang digunakan adalah metode eksperimen semu (Sutama, 2015 : 57). Penelitian ini dilaksanakan di MTs Ta'mirul Islam Surakarta. Penelitian dilaksanakan pada bulan Maret 2016 sampai Juli 2016.

Populasi penelitian ini adalah seluruh siswa kelas VII MTs Ta'mirul Islam Surakarta tahun ajaran 2015/2016 sebanyak 8 kelas. Sampel yang diambil sebanyak dua kelas, siswa kelas VII F sebagai kelas kontrol dalam 
pembelajaran inkuiri terbimbing, siswa kelas VII E sebagai kelas eksperimen dalam pembelajaran inkuiri bebas termodifikasi. Sampling adalah pemilihan sejumlah individu tertentu dari populasi yang ditentukan, sebagai wakil dari populasi tersebut (Sutama, 2015 : 98). Teknik pengambilan sampel menggunakan teknik cluster random sampling dengan undian tanpa pengembalian. Teknik pengumpulan data menggunakan tes kognitif dan metode dokumentasi. Metode tes digunakan untuk mengumpulkan data hasil belajar siswa. Metode dokumentasi digunakan untuk mengumpulkan data kemampuan awal siswa.

Teknik analisis data menggunakan analisis variansi dua jalan dengan sel tak sama. Uji prasyarat meliputi uji normalitas menggunakan metode Liliefors dan uji homogenitas menggunakan metode Bartlett dengan taraf signifikansi 5\% (Budiyono 2009 : 170). Jika pada uji anava $H_{0}$ ditolak, dilakukan uji lanjut pasca anava meliputi uji komparasi ganda antar baris, antar kolom, antar sel pada baris yang sama, antar sel pada kolom yang sama.

\section{Hasil Penelitian dan Pembahasan}

Analisis Data diawali dengan uji keseimbangan sampel. Uji keseimbangan digunakan untuk mengetahui kemampuan awal sampel. Data yang digunakan adalah dokumen nilai ulangan akhir yaitu nilai mid semester genap. Berdasarkan hasil uji t diperoleh $\mathrm{t}_{\text {hitung }}=2,051$ dengan $\mathrm{t}_{\text {tabel }}=2,3109$ Karena $\mathrm{t}_{\text {hitung }}<\mathrm{t}_{\text {tabel, }}$ yaitu 2,051<2,3109 maka Ho diterima, sehingga dapat disimpulkan bahwa sebelum perlakuan kelas inkuiri terbimbing dan inkuiri bebas termodifikasi, kedua sampel mempunyai kemampuan awal yang seimbang.

Kelas VIIF diberi perlakuan dengan pembelajaran strategi inkuiri terbimbing dan kelas VIIE diberi perlakuan dengan pembelajaran inkuiri bebas termodifikasi. Kemudian masing-masing kelas sampel diberikan evaluasi pembelajaran berupa tes kognitif untuk memperoleh data hasil belajar siswa. Berikut deskripsi data hasil belajar matematika :

Tabel 1. Distribusi Frekuensi Nilai Hasil Belajar Kelas Inkuiri Terbimbing

\begin{tabular}{cccc}
\hline Interval & $\begin{array}{c}\text { Titik } \\
\text { Tengah }\end{array}$ & $\begin{array}{c}\text { Frekuensi } \\
\text { Mutlak }\end{array}$ & $\begin{array}{c}\text { Frekuensi } \\
\text { Relatif(\%) }\end{array}$ \\
\hline $44-52$ & 48 & 2 & 7,69 \\
$53-61$ & 57 & 1 & 3,85 \\
$62-70$ & 66 & 4 & 15,39 \\
$71-79$ & 75 & 5 & 19,23 \\
$80-88$ & 84 & 8 & 30,77 \\
$89-97$ & 94 & 6 & 23,08 \\
\hline Jumlah & & 26 & 100 \\
\hline
\end{tabular}

Dari 26 siswa sebagai responden didapatkan nilai terendah 44 dan nilai tertinggi 96. Berdasarkan perhitungan deskrepsi data hasil belajar diperoleh rata-rata untuk kelas 77,62 .

Tabel 2. Distribusi Frekuensi Nilai Hasil Belajar

Kelas inkuiri Bebas Termodifikasi melalui Eksperimen

\begin{tabular}{cccc}
\hline Interval & $\begin{array}{c}\text { Titik } \\
\text { Tengah }\end{array}$ & $\begin{array}{c}\text { Frekuensi } \\
\text { Mutlak }\end{array}$ & $\begin{array}{c}\text { Frekuensi } \\
\text { Relatif(\%) }\end{array}$ \\
\hline $44-51$ & 47,5 & 1 & 3,85 \\
$52-59$ & 55,5 & 2 & 7,69 \\
$60-67$ & 64,5 & 6 & 23,08 \\
$68-75$ & 71,5 & 8 & 30,77 \\
$76-83$ & 79,5 & 3 & 11,54 \\
$84-92$ & 87,5 & 6 & 23,08 \\
\hline \multicolumn{2}{c}{ Jumlah } & 26 & 100 \\
\hline
\end{tabular}

Dari 26 siswa sebagai responden didapatkan nilai terendah 44 , nilai tertinggi 92. Berdasarkan perhitungan deskrepsi data hasil belajar diperoleh rata-rata untuk kelas 70,15 .

Data kemampuan awal diperoleh dengan dokumentasi dari nilai ulangan terakhir, yang kemudian ditransformasikan kedalam skala ordinal dengan kategori tinggi, sedang dan rendah. Menurut Budiyono ( 2011 : 52) 
Untuk kategori tinggi : $\mathrm{M}+1 / 2 \mathrm{SD} \leq \mathrm{x}<\mathrm{M}$ $+1 / 2 \mathrm{SD}$

Untuk kategori sedang: $\mathrm{M}-1 / 2 \mathrm{SD} \leq \mathrm{x}<\mathrm{M}$ $+1 / 2 \mathrm{SD}$

Untuk kategori rendah : $\mathrm{M}-1 / 2 \mathrm{SD} \leq \mathrm{x}<\mathrm{M}$ $-1 / 2 \mathrm{SD}$

Keterangan :

$\mathrm{x}$ : skor siswa

$M$ : nilai rata-rata kelas

SD : Simpangan Baku

Untuk pengelompokkan data kemampuan awal siswa, pada penelitian ini mengambil dokumen nilai ulangan akhir yaitu nilai mid semester genap. Berikut data pengelompokkan kemampuan awal siswa.

Tabel 3. data kemampuan awal siswa pengelompokkan hasil belajar

\begin{tabular}{|c|c|c|c|c|}
\hline \multirow{2}{*}{$\begin{array}{c}\text { Strategi } \\
\text { Pembelajaran } \\
\end{array}$} & \multicolumn{3}{|c|}{ Kemampuan Awal } & \multirow{2}{*}{ Total } \\
\hline & Tinggi & Sedang & Rendah & \\
\hline $\begin{array}{l}\text { Inkuiri } \\
\text { Terbimbing }\end{array}$ & 10 & 6 & 10 & 26 \\
\hline $\begin{array}{l}\text { Inkuiri Bebas } \\
\text { Termodifikasi }\end{array}$ & 9 & 7 & 10 & 26 \\
\hline Total & 19 & 13 & 20 & \\
\hline
\end{tabular}

Tabel 3. Menunjukkan pada kelas inkuiri terbimbing didominasi oleh siswa dengan kemampuan awal kategori tinggi dan kategori rendah rendah. Untuk kelas inkuiri bebas termodifikasi kemampuan awal kategori rendah berbeda tipis dengan ketegori tinggi. jadi antara kelas inkuiri terbimbing dan inkuiri bebas termodifikasi memiliki kemampuan awal yang berbeda-beda.

Untuk rangkuman rataan hasil belajar masing-masing sel dan Rataan marginal adalah sebagai berikut :

Tabel 4. Deskrepsi Data Rangkuman Rataan Hasil Belajar Masing-masing sel dan Rataan marginal

\begin{tabular}{lcccc}
\hline \multicolumn{1}{c}{$\begin{array}{c}\text { Strategi } \\
\text { Pembelajaran }\end{array}$} & \multicolumn{3}{c}{ Kemampuan Awal } & $\begin{array}{c}\text { Rataan } \\
\text { Marginal }\end{array}$ \\
\hline & Tinggi & Sedang & Rendah & \\
\hline $\begin{array}{l}\text { Inkuiri } \\
\text { Terbimbing }\end{array}$ & 86,80 & 77,00 & 68,80 & 77,62 \\
$\begin{array}{l}\text { Inkuiri Bebas } \\
\text { Termodifikasi }\end{array}$ & 80,00 & 68,57 & 62,40 & 70,15 \\
$\begin{array}{l}\text { Rataan } \\
\text { Marginal }\end{array}$ & 83,58 & 72,46 & 65,60 & \\
\hline
\end{tabular}

Tabel 4. Menunjukkan perbedaan ratarata antara kelas inkuiri terbimbing dengan inkuiri bebas termodifikasi. Rata-rata hasil belajar kelas inkuiri terbimbing dengan kemampuan awal kategori tinggi lebih baik dibandingkan dengan kategori sedang maupun rendah. Kemampuan awal kategori sedang memiliki hasil belajar yang lebih baik dibandingkan kategori rendah.

Sebelum uji analisis data, terlebih dahulu data hasil belajar diuji normalitas dan homogenitas sebagai uji prasyarat dengan taraf signifikan 5\%. Setelah perhitungan dilakukan diperoleh hasil uji normalitas faktor hasil belajar dengan strategi inkuiri terbimbing menggunakan SPSS 19.0 didapatkan P-value $=0,200$ untuk uji normalitas dengan Lilliefors (Kolmogorov-Smirnov) dan P-value = 0,190 untuk uji normalitas dengan ShapiroWilk. kedua P-value lebih besar dari $\alpha=$ 0,05 sehingga: $\mathrm{H}_{\mathrm{o}}$ diterima, data berasal dari populasi yang terdistribusi normal.

Hasil uji normalitas faktor hasil belajar untuk kelas inkuiri bebas termodifikasi memiliki $\mathrm{P}$-value $=0,152$ untuk uji normalitas dengan Lilliefors (Kolmogorov-Smirnov) 
dan P-value $=0,264$ untuk uji Shapiro-Wilk. Kedua P-value lebih besar dari $\alpha=0,05$ sehingga: $\mathrm{H}_{\mathrm{o}}$ diterima. Dengan demikian data berasal dari populasi yang terdistribusi normal. Selanjutnya dilakukan uji prasyarat homogenitas. Setelah dilakukan perhitungan diperoleh bahwa sig $>$ taraf sig 0,05 atau $0,452>0,05$ sehingga dapat dikatakan bahwa variabel hasil belajar homogen.
Untuk pengujian hipotesis dilakukan dengan analisis dua jalan sel tak sama pada taraf signifikan5\%. Data hasil penelitian pengaruh model pembelajaran inkuiri terbimbing dan inkuiri bebas termodifikasi terhadap hasil belajar ditinjau dari kemampuan awal siswa dengan hasil perhitungan analisis variansi dua jalan dengan sel tak sama dengan program SPSS 19 adalah sebagai berikut :

Tabel 5. Rangkuman Anava Dua Jalan Dengan Frekuensi Sel Tak Sama

\begin{tabular}{lcccccc}
\hline \multicolumn{1}{c}{ Sumber Variansi } & $\mathbf{J k}$ & $\mathbf{D k}$ & $\mathbf{R k}$ & $\mathbf{F}_{\text {obs }}$ & $\mathbf{F}_{\text {tabel }}$ & Keputusan \\
\hline Strategi (A) & 649,14 & 1 & 649,14 & 5,444 & 4,052 & $\mathrm{H}_{0}$ ditolak \\
Kemampuan Awal (B) & 3103,84 & 2 & 1551,92 & 13,014 & 3,200 & $\mathrm{H}_{0}$ ditolak \\
$\begin{array}{l}\text { Strategi* } \\
\text { Kemampuan Awal (AB) }\end{array}$ & 8,548 & 2 & 4,274 & 0,036 & 3,200 & $\mathrm{H}_{0}$ diterima \\
Galat & 5485,31 & 46 & 119,25 & & & \\
\hline \multicolumn{1}{c}{ Total } & 293188 & 52 & & & & \\
\hline
\end{tabular}

Berdasarkan tabel 5 tampak bahwa semua nilai $\mathrm{F}_{\text {obs }}>\mathrm{F} \alpha$, sehingga diperoleh keputusan uji $\mathrm{H}_{0 \mathrm{~A}}$ ditolak $\mathrm{H}_{0 \mathrm{~B}}$ ditolak dan $\mathrm{H}_{0 \mathrm{AB}}$ diterima. Dengan demikian dapat disimpulkan sebagai berikut :

1. Perbedaan pengaruh pembelajaran berbasis masalah dengan strategi inkuiri terbimbing dan strategi inkuiri bebas termodifikasi terhadap hasil belajar siswa.

Dari hasil anava dua jalan sel tak sama pada taraf signifikansi 5\% diperoleh harga statistik uji $\mathrm{F}_{\mathrm{A}}=5,444$, sedangkan $\mathrm{F}_{\text {tabel }}$ pada tingkat kepercayaan $95 \%(\alpha=0,05)$ dengan $\mathrm{dk}$ $(1 ; 46)=4,052$, berarti $\mathrm{F}_{\mathrm{A}}>\mathrm{F}_{\text {tabel }}$, yaitu 5,444 $>4,052$, maka $\mathrm{H}_{0}$ ditolak. Dengan demikian ada perbedaan yang signifikan penggunaan strategi inkuiri terbimbing dan inkuiri bebas termodifikasi terhadap hasil belajar siswa.

Untuk menentukan strategi pembelajaran yang lebih baik bisa dilihat dari rataratanya. Rata-rata hasil belajar siswa kelas inkuiri terbimbing adalah 77,62 lebih besar dibandingkan rata-rata hasil belajar siswa kelas inkuiri terbimbing yaitu 70,15. I Dewa Putu Nyeneng, dkk (2013), dalam penelitiannya menjelaskan bahwa siswa yang diberi pembelajaran dengan strategi inkuiri terbimbing memiliki hasil belajar lebih tinggi dibandingkan dengan strategi inkuiri bebas termodifikasi.

Hal ini sejalan dengan penelitian yang dilakukan oleh Suparmi (2015), menjelaskan siswa yang belajar dengan model guided inquiry memiliki nilai kemampuan multirepresentasi yang lebih tinggi dibandingkan dengan siswa yang belajar dengan model modified free inquiry. Pembelajaran dengan menggunakan model guided inquiry memiliki beberapa kelebihan yaitu pembelajaran lebih terstruktur, pembelajaran sesuai dengan rancangan yang telah dibuat oleh guru, semua fase dapat terselesaikan, dan siswa lebih mudah dalam belajar karena tidak bingung dengan kegiatan yang harus dikerjakan.

Hasil tersebut didukung dengan kondisi yang ada di lapangan, selama proses pembelajaran pada materi segiempat dan segitiga pembelajaran dengan strategi inkuiri terbimbing siswa terlihat lebih antusias dalam mengikuti bimbingan dan arahan langsung dari guru serta bisa berpartisipasi aktif dalam proses pembelajaran. Setiap anggota dalam kelompok berperan aktif dalam menganalisis masalah yang berkaitan dengan persoalan nyata, Sehingga siswa berperan aktif dalam proses pembelajaran. 
Pada strategi inkuiri bebas termodifikasi, guru hanya memberikan suatu permasalahan dan siswa berusaha dituntut untuk memecahkan masalah tersebut dengan cara melakukan kegiatan ilmiah seperti menganalisis data dan menarik kesimpulan. Pada strategi inkuiri bebas termodifikasi pemecahan masalah dilakukan siswa atas inisiatif dan caranya sendiri. Guru hanya berperan sebagai fasilitator dan sedikit membimbing siswa dengan memberikan pertanyaan-pertanyaan yang sifatnya mengarahkan siswa pada pemecahan masalah, sehingga siswa mengalami kesulitan dalam menyimpulkan permasalahan. Siswa masih takut untuk melangkah dan takut salah.

Dengan demikian dalam penelitian ini, strategi pembelajaran inkuiri terbimbing jika diterapkan pada materi segiempat dan segitiga lebih efektif karena siswa lebih banyak mendapat bimbingan dan arahan dari guru. Menurut penelitian Kadek Budiasa, dkk (2013) strategi guided inquiry memiliki pengaruh positif terhadap keberhasilan akademik dan mengembangkan keterampilan proses ilmiah serta sikap ilmiah siswa.

2. Perbedaan pengaruh kemampuan awal kategori tinggi, kategori sedang dan kategori rendah siswa terhadap hasil belajar siswa.

Dari hasil anava dua jalan sel tak sama pada taraf signifikansi 5\% diperoleh harga statistik uji $\mathrm{F}_{\mathrm{B}}=13,014$, sedangkan $\mathrm{F}_{\text {tabel }}$ pada tingkat kepercayaan $95 \%(\alpha=0,05)$ dengan $\mathrm{dk}=(2 ; 46)=3,200$, berarti $\mathrm{F}_{\mathrm{B}}>\mathrm{F}_{\text {tabel, }}$ yaitu $13,041>3,200$, maka $\mathrm{H}_{0}$ ditolak artinya ada perbedaan yang signifikan hasil belajar siswa ditinjau dari kemampuan awal siswa. Sehingga hipotesis penelitian menunjukkan ada perbedaan yang signifikan antara kemampuan awal siswa dengan kategori tinggi, kategori sedang dan kategori rendah terhadap hasil belajar siswa.

Nilai rata-rata hasil belajar juga menunjukkan ada perbedaan antara kemampuan awal dengan strategi inkuiri terbimbing kategori tinggi yaitu 86,80 , kategori sedang sebesar 77,00 dan kategori rendah sebesar 68,80 . Hal ini menunjukkan bahwa siswa yang memiliki kemampuan awal kategori tinggi dengan pembelajaran strategi inkuiri terbimbing memiliki hasil belajar lebih baik dibandingkan siswa yang memiliki kemampuan awal kategori sedang maupun rendah. Demikian juga nilai ratarata hasil belajar dengan strategi inkuiri bebas termodifikasi dengan kemampuan awal kategori tinggi yaitu 80,00, kategori sedang 68,57 dan kategori rendah sebesar 62,40.

Setiap individu mempunyai kemampuan belajar yang berlainan. Kemampuan awal siswa adalah kemampuan yang telah dimiliki oleh siswa sebelum ia mengikuti pembelajaran yang akan diberikan. Kemampuan awal (entry behavior) ini menggambarkan kesiapan siswa dalam menerima pelajaran yang akan disampaikan oleh guru.(Sumantri,2015 : 183).

Siswa yang mempunyai kemampuan awal kategori tinggi memiliki kelebihan diantaranya siswa lebih aktif dan kreatif, siswa lebih percaya diri, lebih siap dalam melakukan percobaan atau penyelidikan, lebih cepat mendapat data dan menarik kesimpulan, mudah memahami konsep, cenderung lebih tekun dan pantang menyerah, cepat menangkap konsep-konsep baru, isian LKS dan hasil atau laporan penyelidikan juga lebih lengkap. Siswa yang mempunyai kemampuan awal kategori sedang kadangkala terlihat serius kadangkala juga kurang fokus dalam proses pembelajaran, dan siswa yang mempunyai kemampuan awal kategori rendah kenyataan dilapangan memiliki kelemahan diantaranya cenderung pasif, kurang siap dalam percobaan, kurang semangat dalam mengikuti percobaan serta sulit dalam menemukan konsep baru, cenderung kurang tekun dan kurang kemauan.

Hal inilah yang menyebabkan siswa yang memiliki kemampuan awal kategori sedang maupun kategori rendah mempunyai hasil belajar relatif lebih rendah jika dibandingkan dengan siswa yang memiliki kemampuan awal kategori tinggi. Dari kelemahan ini maka perlu adanya solusi diantaranya : perlu 
banyak bimbingan oleh guru, perlu dilakukan pendekatan dengan wawancara agar bisa menggali masalah yang dialami siswa dengan lebih baik pada saat percobaan atau penyelidikan.

Sutrima, dkk (2013), Raed Zedan, Jarmas Bitar (2012) yang menyatakan hasil penelitiannya diperoleh bahwa Siswa dengan kategori kemampuan awal tinggi menghasilkan kemampuan representasi matematik dan kemampuan pemecahan masalah matematik yang lebih baik dibanding dengan siswa dengan kategori kemampuan awal sedang, dan siswa dengan kategori kemampuan awal sedang memiliki kemampuan representasi matematik dan kemampuan pemecahan masalah matematik yang lebih baik dibandingkan siswa dengan kategori kemampuan awal rendah. Dan ada korelasi kemampuan awal matematika dengan prestasi belajar matematika.

Dari hasil penelitian diperoleh kesimpulan bahwa siswa yang memiliki kemampuan awal kategori tinggi mempunyai hasil belajar yang lebih baik daripada siswa dengan kemampuan awal sedang dan rendah. Siswa yang memiliki kemampuan awal kategori sedang mempunyai hasil belajar yang lebih baik daripada siswa yang memiliki kemampuan awal kategori rendah.

3. interaksi antara strategi dengan kemampuan awal kategori tinggi, kategori sedang dan kategori rendah siswa terhadap hasil belajar siswa.

Dari hasil anava dua jalan dengan sel tak sama pada taraf signifikansi 5\% diperoleh bahwa harga statistik uji $\mathrm{F}_{\mathrm{AB}}=0,036$, sedangkan $\mathrm{F}_{\text {tabel }}$ pada tingkat kepercayaan $95 \%(\alpha=0,05)$ dengan $\mathrm{dk}=(2 ; 46)=3,200$, berarti $\mathrm{F}_{\mathrm{AB}}<\mathrm{F}_{\text {tabel, }}$ yaitu $0,036<3,200$, maka $\mathrm{H}_{0}$ diterima, sehingga diperoleh bahwa tidak ada interaksi strategi pembelajaran (inkuiri terbimbing dan inkuiri bebas termodifikasi) dan kemampuan awal siswa terhadap hasil belajar siswa.

Sutrima, dkk (2013) dalam penelitiannya tidak terdapat interaksi antara model pembelajaran dan kemampuan awal siswa terhadap kemampuan representasi dan kemampuan pemecahan masalah matematik siswa. Artinya, baik menggunakan model pembelajaran dengan strategi inkuiri terbimbing maupun pembelajaran dengan strategi inkuiri bebas termodifikasi, siswa dengan kategori kemampuan awal tinggi mempunyai hasil belajar yang lebih baik dibandingkan siswa dengan kategori kemampuan awal sedang dan rendah. Siswa dengan kategori kemampuan awal sedang mempunyai hasil belajar yang lebih baik dibanding siswa dengan kategori kemampuan awal rendah.

Hal ini sejalan dengan penelitian penelitian yang dilakukan oleh Suparmi, dkk (2015) dalam penelitiannya yang menyatakan bahwa tidak ada interaksi model pembelajaran, kemampuan awal dan ketrampilan proses terhadap kemampuan multipresentasi. Pada proses pembelajaran dengan strategi inkuiri terbimbing dan inkuiri bebas termodifikasi, semakin tinggi kemampuan awal yang dimiliki siswa akan semakin tinggi hasil belajarnya. Kenyataan yang terjadi di tempat penelitian pada saat proses percobaan atau penyelidikan terlihat untuk siswa yang mempunyai kemampuan awal tinggi lebih aktif dan tekun dalam proses pembelajaran baik dengan strategi inkuiri terbimbing maupun inkuiri bebas termodifikasi.

Dapat disimpulkan bahwa apapun strategi pembelajaran yang diterapkan siswa yang mempunyai kemampuan awal kategori tinggi akan memperoleh hasil belajar yang lebih baik dari siswa yang mempunyai kemampuan awal kategori sedang maupun rendah. Karena pengaruh yang ditimbulkan saling independen dan dua variabel yang diteliti tidak menghasilkan kombinasi efek yang signifikan, sehingga dapat disimpulkan tidak ada interaksi yang signifikan antara strategi inkuiri terbimbing dan strategi inkuiri bebas termodifikasi dengan kemampuan awal siswa kategori tinggi, kategori sedang dan kategori rendah terhadap hasil belajar siswa. 


\section{Simpulan}

Ada perbedaan pengaruh pembelajaran berbasis masalah dengan strategi inkuiri terbimbing dan strategi inkuiri bebas termodifikasi terhadap hasil belajar siswa. Dengan melihat rata-ratanya menunjukkan bahwa siswa dengan pembelajaran inkuiri terbimbing memiliki hasil belajar lebih baik dibandingkan pembelajaran dengan strategi inkuiri bebas termodifikasi. Hal ini bisa dimengerti karena pada strategi inkuiri terbimbing siswa tidak dilepas begitu saja, siswa lebih banyak mendapat bimbingan guru, siswa diarahkan untuk memecahkan masalah yang telah disampaikan sebelumnya oleh guru melalui gambar, peragaan, atau situasi yang sesungguhnya. Salah satu kelebihan inkuiri terbimbing yaitu guru menjadi teman belajar, terutama dalam situasi penemuan yang jawabanya belum diketahui. Pada strategi inkuiri bebas termodifikasi, guru memberikan suatu permasalahan dan siswa berusaha dituntut untuk memecahkan masalah tersebut dengan cara melakukan kegiatan ilmiah seperti menganalisis data dan menarik kesimpulan yang dilakukan siswa atas inisiatif dan caranya sendiri. Guru hanya berperan sebagai fasilitator dan sedikit membimbing siswa. Hal ini yang menyebabkan hasil belajar siswa menjadi lebih rendah. Maka dapat disimpulkan bahwa siswa yang mendapat pembelajaran dengan strategi inkuiri terbimbing mempunyai hasil belajar yang lebih baik dibandingan dengan siswa yang mendapat pembelajaran dengan inkuiri bebas termodifikasi. Hasil temuan menyatakan ada perbedaan pengaruh antara strategi inkuiri terbimbing dengan strategi inkuiri bebas termodifikasi terhadap hasil belajar siswa.

Ada Perbedaan pengaruh kemampuan awal kategori tinggi, kategori sedang dan kategori rendah siswa terhadap hasil belajar siswa dilihat dari mean siswa yang berkemampuan awal tinggi $>$ mean siswa yang berkemampuan awal sedang maupun rendah $(83,58>72,46>65,6)$. Hal ini bisa dimengerti karena siswa yang memiliki kemampuan awal kategori tinggi lebih aktif dan kreatif, tekun, lebih percaya diri, lebih siap dalam melakukan percobaan atau penyelidikan, mudah memahami konsep dan menangkap konsep-konsep baru. Siswa yang mempunyai kemampuan awal kategori sedang kadang kadang serius kadang-kadang juga kurang fokus dalam proses pembelajaran. Siswa dengan kemampuan awal kategori rendah cenderung pasif, kurang tekun, kurang siap dan kurang semangat dalam mengikuti percobaan, serta sulit dalam menemukan konsep baru.

Siswa yang mempunyai kemampuan awal yang baik akan lebih cepat memahami materi dibandingkan dengan siswa yang tidak mempunyai kemampuan awal dalam proses pembelajaran, sehingga berpengaruh pada perbedaan hasil belajar siswa pada setiap kategori kemampuan awal. Dengan dasar pengetahuan yang tinggi siswa akan lebih berorientasi dalam mengembangkan pemahaman materi pengetahuannya, sedangkan siswa yang kemampuan awalnya masih kurang harus belajar dua kali yaitu memahami materi dasar dan materi yang sedang dipelajarinya. Hasil temuan menyatakan bahwa ada perbedaan pengaruh kemampuan awal kategori tinggi, kategori sedang dan kategori rendah terhadap hasil belajar siswa.

Tidak ada Interaksi antara strategi dengan kemampuan awal kategori tinggi, kategori sedang dan kategori rendah siswa terhadap hasil belajar siswa Dilihat dari mean, siswa yang memiliki kemampuan awal tinggi mendapatkan nilai yang lebih pada strategi inkuiri terbimbing dibandingkan inquiry bebas termodifikasi $(86,8>80)$. Siswa yang memiliki kemampuan awal sedang mendapatkan nilai yang lebih pada strategi inkuiri terbimbing dibandingkan inkuiri bebas termodifikasi $(77>68,57)$. Siswa yang memiliki kemampuan awal rendah mendapatkan nilai yang lebih pada strategi inkuiri terbimbing dibandingkan inkuiri bebas termodifikasi $(68,8>62,4)$.

Strategi pembelajaran yang 
berbeda dalam proses pembelajaran yang disampaikan guru tidak akan merubah kategori kemampuan awal dalam hasil belajarnya. Hal ini dapat dimengerti karena setiap individu mempunyai kemampuan belajar yang berlainan. Kemampuan awal siswa adalah kemampuan yang telah dimiliki oleh siswa sebelum ia mengikuti pembelajaran yang akan diberikan. Kemampuan awal menggambarkan kesiapan siswa dalam menerima pelajaran yang akan disampaikan oleh guru.

Pada proses pembelajaran baik yang menggunakan strategi inkuiri terbimbing maupun inkuiri bebas termodifikasi sama- sama menghasilkan kesimpulan yang sama, bahwa siswa yang memiliki kemampuan awal kategori tinggi selalu lebih baik daripada siswa yang memiliki kemampuan awal kategori sedang dan kategori rendah. Karena pengaruh yang ditimbulkan saling independen dan dua variabel yang diteliti tidak menghasilkan kombinasi efek yang signifikan, hasil temuan menyatakan tidak ada interaksi yang signifikan antara strategi inkuiri terbimbing dan strategi inkuiri bebas termodifikasi dengan kemampuan awal siswa kategori tinggi, kategori sedang dan kategori rendah terhadap hasil belajar siswa.

\section{Daftar Pustaka}

Budiono. 2009. Statistika Untuk Penelitian. Surakarta. Sebelas Maret University Press.

Djamarah, S.B. 2011. Psikologi Belajar. Jakarta. Rineka Cipta.

Fathurrohman, M. 2015. Model-Model Pembelajaran Inovatif. Yogyakarta. Ar-Ruzz Media.

Ghozali, I. (2011). Aplikasi Analisis Multivariate dengan Program IBM SPSS 19. Semarang. Badan Penerbit Undip.

Kadek Budiasa, Viyanti, I Dewa Putu Nyeneng. 2013. "Perbandingan Metode Inkuiri Terbimbing dan Bebas Termodifikasi Terhadap Motivasi dan Hasil Belajar". Jurnal Ilmu Pendidikan Unila, Vol. 3 (4), (1-8).

Sutama. 2015. Metode Penelitian Pendidikan. Surakarta. Fairus Media

Sumantri, MS. 2015.Strategi Pembelajaran. PT Rajagrafindo Persada. Jakarta.

Sanjaya, W. 2011. Strategi Pembelajaran Berorientasi Standar Proses Pendidikan. Jakarta. Kencana Perdana Media.

Suryosubroto. 2009. Proses Belajar Mengajar di Sekolah. Jakarta. Rineka Cipta.

Sudjana. 2005. Dasar-dasar Proses Belajar Mengajar. Bandung. Sinar Baru Algensindo.

Sutrima, dkk. 2013." Perbandingan Kemampuan Representasi Dan Kemampuan Pemecahan Masalah Matematik Pada Siswa Yang Mendapat pembelajaran Kooperatif Disertai Quantum Learning Dengan Siswa Yang Mendapat Pembelajaran Kontekstual Ditinjau Dari Kemampuan Awal Siswa”. Jurnal Penelitian Pendidikan UNS,Vol.1 ( 5)

Suparmi, dkk. 2015. "Pengaruh Pembelajaran Fisika Menggunakan Model Modified Free Inquiry (MFI) dan Guided Inquiri (GI) Terhadap Kemampuan Multirepresentasi Ditinjau Dari Kemampuan Awal Siswa”. Jurnal Penelitian Pendidikan FKIP UNS, ISSN : 22527893, Vol.4 (1). 